Volume 4, No. 3, September - December 2019 ISSN: 2503-4235 (p); 2503-4243 (e)

Shirkah

Journal of Economics and Business 


\section{Shirkah}

Journal of Economics and Business

Vol. 4, No. 3, September-December 2019

ISSN: 2503-4235 (p); 2503-4243 (e)

\section{Editor in Chief}

Fitri Wulandari

\section{Managing Editor}

Jasanta Peranginangin

\section{Editorial Boards}

Abdul Azim Islahi

Islamic Economics Institute, King Abdulaziz University, Saudi Arabia

Abu Umar Faruq Ahmad,

UBD School of Business and Economics Universiti, Brunei Darussalam

Cedomir Nestorovic,

ESSEC Business School Asia Pacific, Singapore

Johan Fischer,

Department of Social Sciences and Business Roskilde Universitetscenter, Denmark Muhamed Zulkhibri,

Islamic Research and Training Institute, Islamic Development Bank, Saudi Arabia M. Kabir Hassan,

Department of Economics and Finance, University of New Orleans, United States Musa Asy'arie,

Faculty of Islamic Economics and Business, IAIN Surakarta, Indonesia

Nunung Nurul Hidayah,

Aston Business School, Aston University, Birmingham, United Kingdom

Saim Kayadibi,

Department of Economics, Kulliyyah of Economics and Management Science,

International Islamic University Malaysia, Malaysia

Shaikh M Ghazanfar,

Departement of Economics, University of Idaho, Russian Federation

Sigit $\mathrm{S}$. Wibowo, 
Department of Management, Faculty of Economics and Business, Universitas Indonesia, Indonesia

Vihang R. Errunza,

Desmarais Global Finance Research Centre, Desautels Faculty and Management, McGill University, Canada

\section{Assistant to Editor \\ M. Endy Saputro \\ M. Zainal Anwar}

Shirkah Journal of Economics and Business is a peer-reviewed journal published three times a year (January-April, May-August and September-December) by Faculty of Islamic Economics and Business, Institut Agama Islam Negeri (IAIN) Surakarta Central Java, Indonesia. The main objective of Shirkah is to offer an academic space of exchange ideas and initiate the increase number of qualified article produced by postgraduate students, practitioners and academicians.

\section{Editorial Office}

Ruang Jurnal Shirkah

Lantai Dasar, Sayap Barat, Fakultas Ekonomi dan Bisnis Islam, IAIN Surakarta

Jln. Pandawa No. 1, Kartasura, Sukoharjo, Jawa Tengah Kode Pos. 57168

Phone (+62271) 781516 Fax: (+62271)782336

E-mail: shirkahjournal@iainsurakarta.ac.id; shirkahiainsurakarta@gmail.com

Website: http://shirkah.or.id/ 


\section{Shirkah}

Journal of Economics and Business

Vol. 3, No. 3, September-December 2018

ISSN: 2503-4235 (p); 2503-4243 (e)

\section{Table of Contents}

\section{Articles}

M. Falikul Isbah

External Influences and Supports to Pesantren's Socio-Economic

Activism in Changing Context

R. Lukman Fauroni

The Economic Community of Pesantren Al-Ittifaq Opposing

Market Capitalism and the Improvement of Competitiveness

M. Musa Al Hasyim

403

Creative Industry Development in Pesantren Tebuireng

Kuat Ismanto

N. Nasrullah

429

Multiplier Effects of Pesantren Walindo

Mustaghfiroh Rahayu

455

Social Embeddedness and Economic Behaviour in Pesantren Mlangi

Helmi Haris

Muhammad Nashirudin

481

Lombok as an Indonesian Halal Travel Destination 


\title{
Lombok as An Indonesian Halal Travel Destination
}

\author{
Helmi Haris \\ Doctoral Student, Islamic Economics, \\ Universitas Islam Negeri Sunan Kalijaga, Yogyakarta \\ helmi.solo@gmail.com \\ Muhammad Nashirudin \\ Faculty of Sharia, IAIN Surakarta \\ muh.nashirudin@gmail.com
}

\begin{abstract}
This study examines Lombok, as an Indonesian halal travel destination, through Global Muslim Travel Index (GMTI) analysis. GMTI requires four main indicators of assessing a halal destination, namely access, communication, environment and service. This study finds that Lombok is a promising island to be a halal travel destination, even it will be the best halal tourism place in Indonesia. However, the development of this destination should put in priority. The local government should take part in translating the halal destination concept to the grassroot level of tourism industry, whether in terms of tradition, culture, environment and other main indicators.
\end{abstract}

Keywords: Lombok, halal tourism, travel destination, GMTI

\section{Introduction}

GMTI (Global Moslem Travel Index) is one of the halal tourism indexing sites throughout the world. Indonesia's position in the GMTI release continued to increase. In 2014, Indonesia in 6th, 4th in 2015, 3rd in 2016 and second place in 2017. GMTI release at www.crescentrating. com feasible to be used as one of the studies of its influence on halal tourism in Lombok, West Nusa Tenggara (NTB). Lombok is worthy of being studied as it won 2 categories from 3 categories obtained by Indonesia 
in the 2015 World Halal Tourism Award for the category of World Best Halal Tourism Destination and World Best Honeymoon Destination. Indonesia getting awards in 2016 in three categories, the World's Best Halal Beach Resort, for Novotel Lombok Resort \& Villas, Lombok, the category of the World's Best Halal Tourism Website for the website www. wonderfullomboksumbawa.com and the category of the World's Best Halal Honeymoon Destination for Sembalun Village Region, Lombok. This paper describes the conditions of halal tourism in Lombok, NTB, and analyzes it using the GMTI indicators.

There are several studies on halal tourism in Indonesia and especially about Lombok. Alif Fajri wrote about the influence of World Halal Tourism in West Sumatra. (Fajri, nd), but did not make GMTI an indicator of the influence of West Sumatra's success in winning the World Halal Tourism award, as well as the writings of Pratiwi, Dida and Syarifah about Communication Strategies in Building Halal Tourism Awareness in Bandung City (Pratiwi, Dida, \& Sjafirah, 2018). The writing of Aan Jaelani also only looks at the potential and prospects of halal tourism in Indonesia after Indonesia received an award at the 2016 World Halal Tourism Awards in 12 categories (Jaelani, 2017).

Hafizah Awalia discusses halal tourism in NTB as part of the government's capital control and domination of NTB areas by the government (Awalia, 2017). Subarkah wrote about the importance of public diplomacy through halal certification and community involvement in tourism conscious aspects in NTB as part of the success of halal tourism (Subarkah, 2018). Fahadil Amin al Hasan wrote about the Implementation of Halal Tourism in Indonesia, but only looked at the theme with the perspective of the MUI DSN Fatwa on Tourism Implementation Based on Sharia Principles (Al Hasan, 2017). Abdul Kadir Jaelani wrote an article aimed at knowing and analyzing the background of the birth of Halal Tourism development in West Nusa Tenggara Province and the obstacles 
experienced in implementing Halal Tourism Regulations and the efforts made by the Regional Government, and not connecting them with GMTI (Jaelani, 2018).

There are four indicators by GMTI for ranking, namely access (access), communication (communications), environment (environment) and services (services). These four indicators are used as a tool to analyze halal tourism in West Nusa Tenggara or Lombok. The four indicators are then broken down into several more indicators, including: access; access includes the ease of obtaining a visa (visa requirements), flight connectivity (air connectivity), and transportation infrastructure (transport infrastructure). Communication; communication includes outreach indicators, ease of communication, and ease of digital communication. Environment; the indicators included in the environmental category are security and culture (safety and culture), tourist arrivals (visitor arrivals), enabling climate. Services; service indicator is basic needs (food, drinks and worship) or core needs (halal food and prayers), basic services (hotels, airports) or core services (hotels, airports), and unique experiences (https: //www.crescentrating.com).

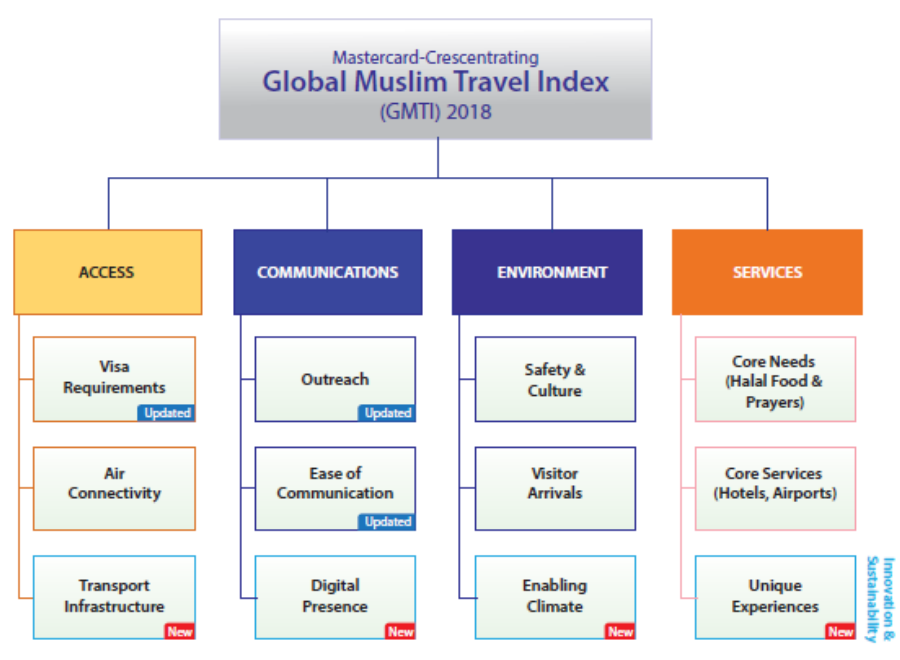

Figure 1. Global Muslim Travel Index

Vol. 4 No. 3, September - December 2019 


\section{Lombok under GMTI}

When Lombok managed to win 2 categories from 3 categories obtained by Indonesia in the 2015 World Halal Tourism Award for the category of World Best Halal Tourism Destination and World Best Honeymoon Destination, the NTB Governor Muhammad Zainul Majdi moved quickly to build Lombok's image and branding as a tourism distortion halal. The 2015 award continued in 2016 with awards in three categories, namely World's Best Halal Beach Resort, namely Novotel Lombok Resort \& Villas, Lombok, the category of the World's Best Halal Tourism Website for the website www.wonderfullomboksumbawa.com and the World's Best Halal category Honeymoon Destination for Sembalun Village Region, Lombok. Among the rapid movements carried out by the NTB Regional Government were issuing Regional Regulations (Perda) No. 2 of 2016 concerning Halal Tourism. Among the important points in the Regional Regulation are regulating the scope of sharia tourism which includes destinations, marketing and promotion, industry, institutions, guidance, supervision and financing. The regulation also requires halal tourism destination managers to build public facilities that support the convenience of halal tourism activities, such as places and equipment for Muslim tourist worship, as well as purification facilities that meet sharia standards.

Since it was declared a halal tourist destination in Indonesia, Lombok has experienced rapid development in accepting tourists, both domestic and foreign. Data from the Central Statistics Agency (BPS) through the bps.go.id website shows that tourists to Lombok increased by $50 \%$ in 2017 compared to the previous year. That is, halal tourism branding echoed by the NTB Regional Government received a positive response from the tourists. However, as information obtained from the West Nusa Tenggara BPPD (Regional Tourism Promotion Agency) 
through its Public Relations, Zul Hakim, halal tourism branding still faces several obstacles, both at the level of coordination and understanding of halal tourism in NTB.

This obstacle to coordination and understanding is, for example, the lack of full authority of the regional government in determining policies at the district government level in NTB. This halal tourism branding policy is not all regents accept it well, both for political reasons and the reasons for good communication are well established. Not all stakeholders related to halal tourism can immediately understand well the positive impact of halal tourism branding for NTB.

MUI as one of the partners of the NTB Regional Government has not been able to accept the term "halal" in the criteria proposed by GMTI because it is still carried away by understanding diametrically opposed halal words and vis a vis in the forbidden word in the figh realm. Business people, such as restaurants, hotels, tourist attractions are also concerned that halal branding in halal tourism will make their conventional market so far, namely foreign tourists from America, Europe and other non-Muslim majority countries will run away from them, and yet there is certainty that tourists from the Arab world and Muslim tourists from other countries can be sucked into NTB with halal tourism branding.

The BPPD, in this case, seeks to bridge some of the obstacles associated with this. In several coordination meetings conducted by $\mathrm{BPPD}$, according to Zul Hakim's explanation, MUI was asked to take a more active role in conducting certification, especially hotels. This role at least provides space for the MUI to supervise and evaluate hotels in implementing halal tourism in NTB. BPPD is also trying to convince business people, especially hotels and tourist destinations, that halal tourism branding in NTB will not erode the number of conventional tourism that has existed, but basically it creates a new market that is currently 
experiencing an increasing trend throughout the world, namely Muslim tourist market. Moreover, so far, tourists from Arab countries and majority Muslim countries have not worked well in NTB. The BPPD also provides proposals for hotel certification to be intact or partial. Full certification means that all hotel services are based on sharia services, both in terms of food and beverages and pre-facility facilities. Whereas partial certificates mean that sharia service in one hotel is only valid for some rooms of all rooms provided by a hotel. That is, it could be that some rooms already meet sharia standards, while some of the other rooms do not meet the feasibility of being a sharia service room.

These constraints are then used as input for the NTB Government and the BPPD to "soften" the term halal tourism or sharia tourism in NTB to become a more accepted term for the general public and tourism stakeholders in NTB, namely Muslim friendly. The term Muslim friendly is currently used more by the Malaysian government to market halal tourism in Malaysia. It's just that, if this term is perceived to be more easily accepted by internal stakeholders in NTB such as the MUI, business people and the NTB community as well as external stakeholders such as domestic and foreign tourists, it is certainly worth considering as a term used for tourism branding in NTB.

Another obstacle faced is socialization to the public about halal tourism. Meninting area in West Lombok which is one of the areas that will be developed as Halal Beach area in Lombok besides Mandalika in North Lombok, for example, has yet to feel concrete information about the development of halal tourism in the region. The Meninting Village Chief, Iskandar Zulkarnain, in an interview that the researchers did, said that there was no clear outreach to date about how Meninting Village would be identified as a halal beach area. Therefore, none of the budget posts in Meninting Village leads to the development of halal tourism. Iskandar 
said that until now, all he knew was the Meninting Village landscape plan proposed by investors facilitated by the NTB Government. However, the landscape has not been declared based on halal tourism or halal beaches in NTB. In addition, the landscape of Meninting beach is still constrained by land acquisition and relocation policies of affected people that have not yet been discussed.

\section{Potential Access Indicators}

The central government policy of the Republic of Indonesia for infrastructure development in parts of Indonesia, especially outside Java, has a significant impact on these accessibility indicators. The construction of Lombok International Airport in Praya with a very adequate capacity makes tourists from various regions can easily get flight access to NTB. There are many airports in Indonesia that are directly connected to Lombok International Airport, except that connectivity with airports abroad is still very minimal if it has the target of making Lombok a tourist destination that is at least comparable to Bali which is adjacent to NTB.

Road access to a number of regions which are the main tourist destinations in NTB is also very good. However, in terms of adequacy, the means of mass transportation in NTB are far from enough. If the potential for this indicator can be increased, the number of foreign tourists visiting Lombok will be even greater.

\section{Potential of Communication Indicators}

At present the ease of communication is a very important factor in attracting tourists. In this case, Lombok is an area that is not very troubled by communication problems. The communication service network and its reach are adequate for areas that are the mainstay destinations in NTB such 
as West Lombok and Mataram. However, there are still many suburban areas that have very good tourism potential, but there are many blind spots of telecommunication networks which of course will be a big obstacle for the development of tourist areas.

External communication in the form of publications about events and calendar of tourist activities in NTB is also very minimal. The official BPPD website which is one of the "mouthpieces" of tourism in NTB until the time this research was conducted was still in a state of improvement. The researcher gave a proposal to the BPPD to create a site that had at least three languages; Indonesia, Britain and Arabia to maximize the potential for publication to tourists from countries based on Arabic.

\section{Potential Environmental Indicators}

The environment is the biggest potential that NTB has for tourism development, especially halal tourism. The majority of Muslim societies with a devout and tolerant Islamic culture are the factors that make the environment in NTB comfortable and safe. Natural resources (SDA) owned by NTB are also very large and still have enormous potential to be developed.

The tourist destinations offered by NTB are very diverse, in the form of mountains (Rinjani, Tambora), beaches (Senggigi), islands (3 gili), traditional villages (Sade Village), as well as performances of traditional Sasak arts. Even now, since it was opened by the President of the Republic of Indonesia in 2017, North Lobok has developed Kuta as a very reliable tourist destination, and has made Mandalika a Special Economic Zone (SEZ) with the characteristics of halal tourism. KEK Mandalika is claimed as a maritime tourism destination and cultural tourism with exotic panoramas and adjacent to the Island of the Gods of Bali, and is expected to attract a visit of 2 million foreign tourists per year in 2019. KEK Mandalika 
has the concept of environmentally friendly tourism development with the construction of tourism objects and tourist attraction that is always oriented to the preservation of the value and quality of the environment in the community. KEK Mandalika is the most attractive SEZ for investors now and it is hoped that in the future this region will become a world-class tourist destination. (http://kek.go.id/kawasan/Mandalika\#).

The weather in NTB is also very supportive of tourism because it does not find extreme weather, either extreme heat or extreme high, with coastal areas and mountains that are almost as potential. It's just that this earthquake that occurred in early August 2018 will certainly have an impact on tourism in NTB even though it may only be in the short term.

\section{Potential Service Indicators}

The service indicators at GMTI are also the indicators with the greatest potential in NTB. Core Needs in the GMTI service indicator in the form of halal food and prayers have even become services that have existed in NTB since before being designated as halal tourism areas. As a region with a majority of Muslims, it is almost certain that food and beverages in the NTB region are halal food and beverages. The perspective of halal food and beverages is worthy of being taken into consideration in some regions in Indonesia which are mostly non-Muslim, such as Bali or in some cities in a country that is predominantly non-Muslim such as Bangkok. This perspective becomes less relevant in Lombok considering that the majority of Lombok people only consume halal food and beverages.

Likewise with the places of worship. Lombok, known as Pulau Seribu Masjid, is an icon that is very "selling" for halal tourism, and making indicators of services related to places of worship have very good value. Places of worship for Muslims can not only be found inside the hotel, but around the hotel, tourists will find mosques and prayer rooms very easily. 
The tools to facilitate the implementation of worship such as the Qibla direction, prayer rug, mukena, mushaf are not only easily available at the hotel, but the mosque which is close to the hotel and the NTB community settlement has provided it very well.

Unique Experiences that are the selling points that can best distinguish between one tourist destination, and basically Lombok has a lot of local wisdom that can be explored to be used as a material that sells the unique experiences of tourists when traveling on Lombok. The richness of the culture and customs of the people of Lombok, both Islamic culture and Sasak culture makes Lombok have a different selling value than other regions in Indonesia.

\section{Conclusion}

Lombok, as a halal tourism destination, is very promising. Especially when viewed from the GMTI indicator, Lombok is one of the best. But what needs to be considered by stakeholders in halal tourism development in Lombok, especially the Government, is how to manifest the meaning of halal tourism to the lowest level of tourism industry players in West Nusa Tenggara. Because actually in terms of tradition, culture, environment and other tools, Lombok is very suitable for the development of halal tourism in Indonesia. 


\section{References}

Al Hasan, F. A. (2017). Penyelenggaraan Parawisata Halal di Indonesia (Analisis Fatwa DSN-MUI tentang Pedoman Penyelenggaraan Pariwisata Berdasarkan Prinsip Syariah). Al-Abkam, 2(1), 59-78. https://doi.org/10.22515/al-ahkam.v2i1.699

Awalia, H. (2017). Komodifikasi Pariwisata Halal NTB dalam Promosi Destinasi Wisata Islami di Indonesia. Jurnal Studi Komunikasi, 1(1). Retrieved from www.disbudparntb.com

Fajri, A. (n.d.). Pengaruh World Halal Tourism terhadap Pertumbuhan Wisatawan Mancanegara Objek Wisata Sumatera Barat. Retrieved from https://www.academia.edu/35762742/Pengaruh_World_Halal_ Tourism_Terhadap_Pertumbuhan_Wisatawan_Mancanegara_ Objek_Wisata_Sumatera_Barat

Jaelani, A. (2017). Industri Wisata Halal di Indonesia: Potensi dan Prospek. Retrieved from https://mpra.ub.uni-muenchen.de/76237/

Jaelani, A. K. (2018). Pengembangan Destinasi Pariwisata Halal Pada Era Otonomi Luas di Provinsi Nusa Tenggara Barat. Pariwisata, 5(1). Retrieved from http://ejournal.bsi.ac.id/ejurnal/index.php/jp56

Pratiwi, S. R., Dida, S., \& Sjafirah, N. A. (2018). Strategi Komunikasi dalam Membangun Awareness Wisata Halal di Kota Bandung. Jurnal Kajian Komunikasi, 6(1).

Subarkah, A. R. (2018). Diplomasi Pariwisata Halal Nusa Tenggara Barat. Intermestic: Journal of International Studies, 2(2). https://oi. org/10.24198/intermestic.v2n2.6 


\section{Shirkah Author Guidelines}

Shirkah currently offers two routes to submit manuscripts. We highly recommend to submit the articles which are made using OJS (Open Journal System). Feel free register as author soon through visiting http:// shirkah.or.id/index.php/home/user/register. The authors may directly send their manuscripts, along with their resume, to shirkahiainsurakarta@ gmail.com. Please prepare your manuscripts, using following guidelines:

1. Manuscript must be written in English. Submitted articles should not have been published or be under review for publication with another journal.

2. Manuscript's length is about $15-20$ pages, typed in one-half spaced on A4-paper size.

3. Manuscript must include an $150-200$ word abstract and keywords.

4. Manuscript must be arranged as follows: Title, Name of Author, E-mail address, Abstract, Keywords, Introduction (including method if any), Discussion, Conclusion, References.

5. Manuscript's titles not more than ten words.

6. Manuscript must be submitted in Microsoft Word or RTF.

7. Arabic words should be transliterated according to the style of International Journal of Middle Eastern Studies.

8. Manuscript references are preferably derived from the up-to-date references.

9. The author's resume should be submitted separately, consisting of at least full name, institutional address, phone number, areas of studies, and recent publications (if any).

10. Shirkab use APA Style 6th edition (2010) as reference format writing. We suggest the use of a reference manager software such as Mendeley, Zotero, and Endnote at templating the citation style. APA Style to be used is as follows: 


\section{Book with single author}

Swann, G. M. Peter. (2014). The Economics of Innovation an Introduction. Cheltenhum \& Northampton: Edward Elgar.

in-text citation: (Swann, 2014)

\section{Articles in reference books}

Alatas, S. F. (2006). Islam and the Science of Economics in Abu Rabi', I.M. The Blackwell Companion to Contemporary Islamic Thought. USA: Willey-Blackwell (pp. 587-606).

in text citation: (Alatas, 2006)

\section{E-Book}

Hackett, Rosalind (2007). "Religous Dimentions of War and Peace: Introduction.” Dalam Gerrie ter Haar dan Yoshio Tsuruoka (Ed.), Religion and Society: An Agenda for the 21st Century (h. 3-6). Retrieved from http:// brill.nl.

in text citation: (Hackett, 2006)

\section{Master's thesis, from a commercial database}

McNieI, D. S. (2006). Meaning through narrative: A personal narrative discussing growing up with an alcoholic mother (Master's thesis). Available from ProQuest Dissertations and Theses database. (UMI No. 1434728)

in text citation: (Mc Niel, 2006)

\section{Doctoral dissertation, from an institutional database}

Adams, R. J. (1973). Building a foundation for evaluation of instruction in higher education and continuing education (Doctoral dissertation). Retrieved from http://www.ohiolink.edu/etd/

in text citation: (Adams, 1973) 


\section{Doctoral dissertation, from the web}

Bruckman, A. (1997). MOOSE Crossing: Construction, community, and learning in a networked virtual world for kids (Doctoral dissertation, Massachusetts Institute of Technology). Retrieved from http:/www-static. cc.gatech.edu/--asb/thesis/

in text citation: (Bruckman, 1997)

\section{Journal article with No DOI}

Bourkhis, K., and Nabi, M. S. (2013). Islamic and conventional banks' soundness during the 2007-2008 financial crisis. Journal Metrics, 22(2), 68-77.

in-text citation: (Bourkhis \& Nabi, 2013).

\section{Journal article with DOI}

Ichwan, M. (2012). The Local Politics Of Orthodoxy: The Majelis Ulama Indonesia in the Post-New Order Banten. Journal Of Indonesian Islam, 6(1), 166-194. doi:http://dx.doi.org/10.15642/JIIS.2012.6.1.166-194

In text citation : (Ichwan, 2012)

\section{Abstract as citation}

Hasan, N. (2012). Islamist Party, Electoral Politics And Da'wah Mobilization Among Youth : The Prosperous Justice Party (PKS) in Indonesia. Journal of Indonesian Islam, 6(1), 17-47. Abstract from http:// jiis.uinsby.ac.id/index.php/jiis/article/view/97

in text citation : (Hasan, 2012)

\section{Mass media article}

Sahal, Akhmad (2014, March 2). Kiai Sahal dan Realisme Fikih.Tempo Magazine, p. 120.

in text citation : (Sahal, 2014) 


\section{Research report}

Fisher, B. S., Cullen, F. T., \& Turner, M. G. (2000). The Sexual Victimization of College Women. Research Report.

in text citation : (Fisher, Cullen, Turner, 2000)

\section{Monograph}

Routray, Bibhu Prasad (2013), National Security Decision-Making in India (RSIS Monograph No. 27). Singapura: Rajaratnam School of International Studies.

in text citation : (Routray, 2013)

\section{Proceeding article}

Sudibyakto, Hizbaron, D.R., \& Jati, R (Ed.) (2009), Proceeding International Seminar Disaster Theory, Research and Policy. International seminar held by Sekolah Pascasarjana, Universitas Gajahmada, Yogyakarta, 8-9 Desember 2009.

in text citation : (sudibyakto and Jati, 2009)

\section{Paper conference/seminar/symposium}

Janutama, Herman Sinung (2011). "Kraton dan Hubungan Antar Agama." Paper presented in Seminar Kraton dan Panatagama held by Center for the Study of Islam and Social Transformation (CISForm), Yogyakarta, 17 November.

$$
\text { in text citation :(Janutama, 2011) }
$$

\section{Online article in web}

Shiva, (2006, February). Bioethics: A Third World Issue. Native-web. Diperoleh dari http://www.nativeweb.org/ pages/legal/shiva.html 


\section{in text citation : (Shiva, 2006)}

\section{Online research report}

Kessy, S. S. A., \& Urio, F M. (2006). The contribution of microfinance institutions to poverty reduction in Tanzania (Research Report No. 06.3). Retrieved from Research on Poverty Alleviation website: http://www. repoa.or.tz /documents_storage/Publications/Reports/06.3_Kessy_and_ Urio.pcif

in text citation : (kessy and urion, 2006)

\section{Holy book}

Qur an, $2(25)$

In text citation : (Q. al-Baqarah 2:25).

\section{Encyclopaedia}

Graycar, Adam (1992). Social Welfare Policy. Dalam Mary Hawkesworth dan Maurice Kogan (Ed.), Encyclopedia of Government and Politics (Vol. 1). London: Routledge.

in text citation : (Graycar, 1992)

\section{Interview}

Sultan Hamengkubuwono X (interview, 2011, April 19)

in text citation : (Hamengkubuwono, 2011)

\section{Documentary film}

Steijlen, Fridus (2008). A Day in the Life of Indonesia [documentary film, 58 minutes]. Leiden: KITLV Press.

in text citation : (Steijlen, 2008) 
Vol. 4 No. 3, September - December 2019 